OAK RIDGE NATIONAL LABORATORY

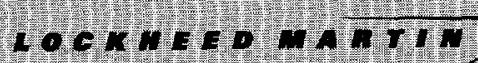

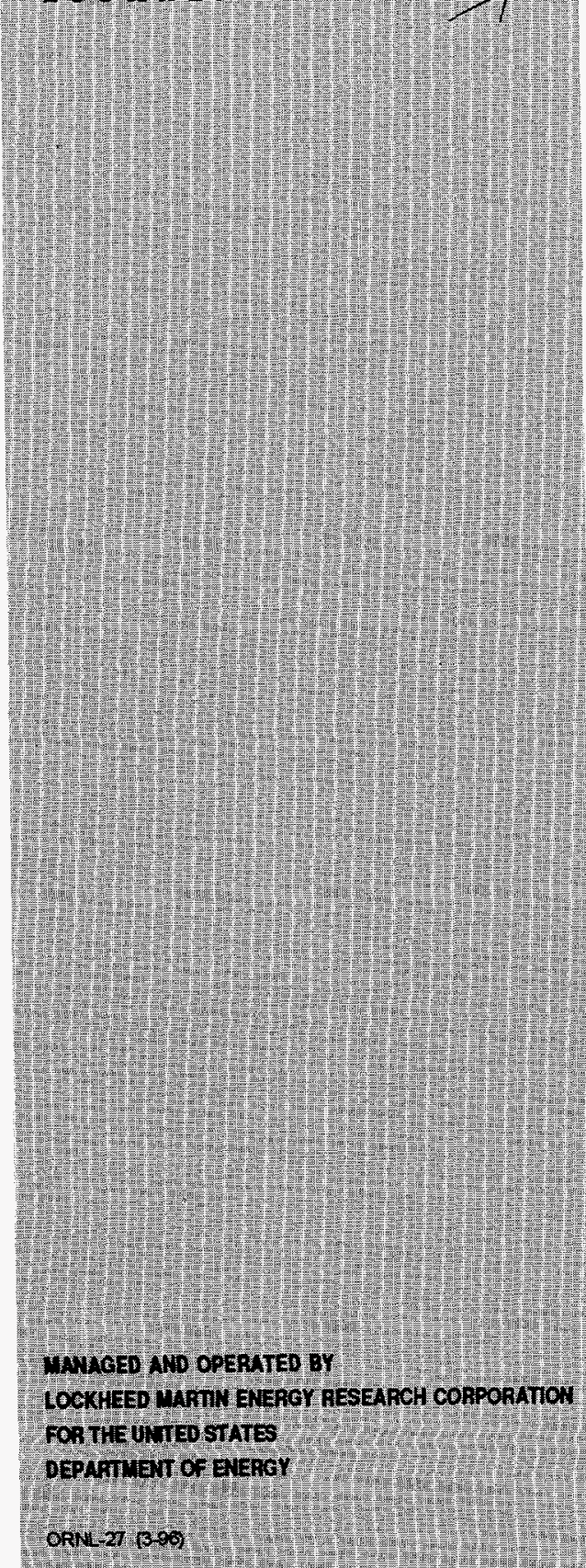

\section{Project Plan for the Evaluation of REDC Waste for TRU-Waste Radionuclides}

$$
\begin{aligned}
& \text { AECEIVED } \\
& \text { NOVO } 81996 \\
& \text { OSTI }
\end{aligned}
$$

J. Chapman

J. Beauchamp

D. Downing

V. Fedorov

C. Parks

R. Schreiber

F. Schultz

\title{
MASTER
}


This report has been reproduced directly from the best available copy.

Available to DOE and DOE contractors from the Office of Scientific and Technical Information, P. O. Box 62, Oak Ridge, TN 37831: prices available from (423) 576-8401, FTS 626-8401.

Available to the public from the National Technical Information Service, U.S. Department of Commerce, 5285 Port Royal Road, Springfield. VA 22161.

This report was prepared as an account of work sponsored by an agency of the United States Government. Neither the United States Government nor any agency thereof, nor any of their employees, makes any warranty, express or implied, or assumes any legal liability or responsibility for the accuracy, completeness, or usefulness of any information, apparatus, product, or process disclosed, or represents that its use would not infringe privately owned rights. Reference herein to any specific commercial product, process, or service by trade name, trademark, manufacturer, or otherwise, does not necessarily constitute or imply its endorsement. recommendation, or favoring by the United States Government or any agency thereof. The views and opinions of authors expressed herein do not necessarily state or reflect those of the United States Government of any agency thereof. 


\title{
Waste Management and Remedial Action Division
}

\section{PROJECT PLAN \\ FOR THE \\ EVALUATION OF REDC WASTE FOR TRU-WASTE RADIONUCLIDES}

\author{
L. Nguyen ${ }^{1}$, L. Yong ${ }^{2}$, J. Chapman ${ }^{1}$ \\ J. Beauchamp ${ }^{3}$, D. Downing ${ }^{3}$, \\ V. Fedorov ${ }^{3}$, C. Parks ${ }^{4}$, R. Schreiber ${ }^{5}$, F. Schultz ${ }^{1}$ \\ ${ }^{1}$ Waste Management and Remedial Action Division, ORNL \\ ${ }^{2}$ Advanced Integrated Management Services, Inc., Oak Ridge, TN 37831 \\ ${ }^{3}$ Computer Science and Mathematics Division, ORNL \\ ${ }^{4}$ Chemical and Analytical Science Division, ORNL \\ ${ }^{5}$ Chemical Technology Division, ORNL
}

Date Published - September 1996

NOTICE: This document contains information of a preliminary nature. It is subject to revision or correction and therefore does not represent a final report

Prepared by

OAK RIDGE NATIONAL LABORATORY

Oak Ridge, Tennessee 37831-6285

managed by

LOCKHEED MARTIN ENERGY RESEARCH CORP.

for the

U.S. DEPARTMENT OF ENERGY

under contract DE-AC05-96OR22464 


\section{DISCLAIMER}

Portions of this document may be illegible in electronic image products. Images are produced from the best available original document. 


\section{TABLE OF CONTENTS}

\section{Page}

LIST OF FIGURES $\ldots \ldots \ldots \ldots \ldots \ldots \ldots \ldots \ldots \ldots \ldots \ldots \ldots \ldots$

LIST OF TABLES $\ldots \ldots \ldots \ldots \ldots \ldots \ldots \ldots \ldots \ldots \ldots \ldots \ldots$ iii

LIST OF ACRONYMS $\ldots \ldots \ldots \ldots \ldots \ldots \ldots \ldots \ldots \ldots \ldots \ldots$ iv

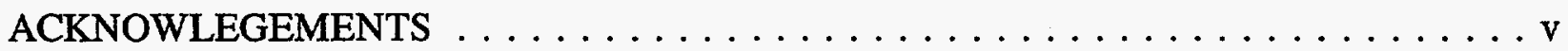

EXECUTIVE SUMMARY $\ldots \ldots \ldots \ldots \ldots \ldots \ldots \ldots \ldots \ldots \ldots \ldots$

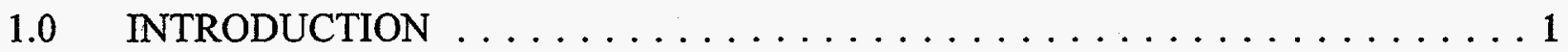

$2.0 \quad$ BACKGROUND $\ldots \ldots \ldots \ldots \ldots \ldots \ldots \ldots \ldots \ldots \ldots \ldots \ldots \ldots \ldots \ldots$

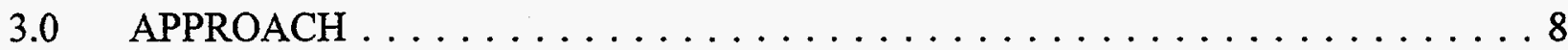

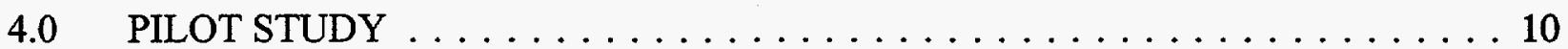

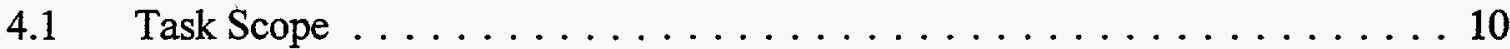

4.2 Method for Sampling and Analysis . . . . . . . . . . . . . 10

4.3 Analysis of the Sampling Results $\ldots \ldots \ldots \ldots \ldots \ldots \ldots$

4.4 Reporting of Results . . . . . . . . . . . . . . . 12

5.0 PRIMARY CHARACTERIZATION OF REDC CH-TRU WASTE . . . . . . . . . 13

$5.1 \quad$ Nondestructive Assay and Examination . . . . . . . . . . . . 13

5.2 Destructive Radiological Analyses . . . . . . . . . . . . . . 14

5.3 Data Evaluation Activities . . . . . . . . . . . . . . . . . 16

5.4 Correlate NDA Measured Radionuclides with TRU Radionuclides . . . . . . . 17

5.5 REDC Waste Characterization Report . . . . . . . . . . . . . . 18

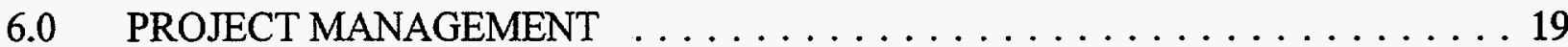

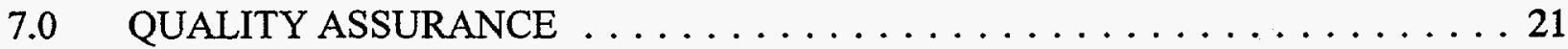

$8.0 \quad$ PROJECTED SCHEDULE AND COST $\ldots \ldots \ldots \ldots \ldots \ldots \ldots \ldots$

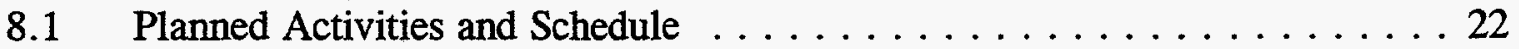

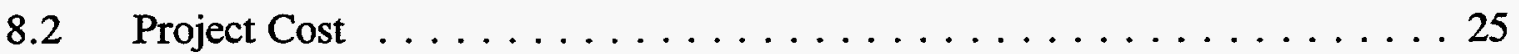

REFERENCES 


\section{LIST OF TABLES}

Page

Table 2.1 Characterization of REDC Solid Wastes . . . . . . . . . . . . 5

Table 2.2 List of Potential Radionuclides Present in REDC TRU Solid Wastes . . . . . 7

Table $5.1 \quad$ Analytical Test Methods . . . . . . . . . . . . . . . . 15

Table $6.1 \quad$ Project Responsibilities . . . . . . . . . . . . . . . 20

Table $8.1 \quad$ FY 1996 Milestones . . . . . . . . . . . . . . . . . . 22

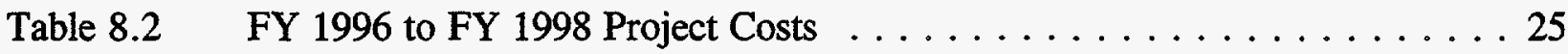




\section{LIST OF FIGURES}

Page

Figure 8.1 FY 1996 Project Flowchart for NDA and Destructive Assay Activities . . . 23

Figure $8.2 \quad$ Planned Activities for FY $1996 \ldots \ldots \ldots \ldots \ldots \ldots \ldots \ldots \ldots \ldots \ldots \ldots$ 


\section{LIST OF ACRONYMS}

APNEA Active Passive Neutron Examination and Assay

A.RMD Applied Radiation Measurements Department

CASD Chemical and Analytical Sciences Division

CH Contact Handled

CS\&MD Computer Science and Mathematics Division

DA Destructive Assay

DOE Department of Energy

GCO Generator Certification Official

HFIR High Flux Isotope Reactor

NDA Nondestructive Assay

NTP National TRU Program

ORNL Oak Ridge National Laboratory

PTS Progress Tracking System

QAPP Quality Assurance Program Plan

REDC Radiochemical Engineering Development Center

RH Remote Handled

SRP Savannah River Plant

TRU Transuranic

WAC Waste Acceptance Criteria

WEAF Waste Examination and Assay Facility

WIPP Waste Isolation Pilot Plant

WMRAD Waste Management and Remedial Action Division 


\section{ACKNOWLEDGMENTS}

This report would not have been possible without the critical insight and guidance provided to the project team by J. R. Trabalka. In addition, the project team wishes to thank R. M. Wham and C. W. Evans for their help and cooperation. 


\section{EXECUTIVE SUMMARY}

This Project Plan describes the plan to determine whether the solid radioactive wastes generated by the Radiochemical Engineering Development Center (REDC) meet the Department of Energy's definition of transuranic (TRU) wastes. The scope of this project is to (a) assess existing REDC waste characterization methods, (b) evaluate historical data and to collect samples of newly generated REDC wastes for analysis, (c) make recommendations for modifications to the REDC waste certification procedure as needed, and (d) if the determination is made that REDC wastes are TRU wastes, to provide direction to REDC on characterizing the newly generated wastes to meet the Waste Isolation Pilot Plant Waste Acceptance Criteria. The strategy for making this determination is based on performing nondestructive assay (NDA), complemented with destructive assay, of newly generated contact-handled $(\mathrm{CH})$ waste from the REDC. CH waste will be used in the characterization exercise for technical, safety, and health reasons. It is anticipated that the legacy wastes can be classified based on the evaluation of the $\mathrm{CH}$ waste. To support the NDA activities, a pilot study will be performed with the aim of establishing radionuclide profiles in terms of locality and waste material, and potentially identifying locations for obtaining samples for NDA within the hot cells. The NDA will be performed at the Waste Assay and Examination Facility, using active-passive neutron assay and gamma spectroscopy techniques. Along with the actual REDC waste, radioactive mock-ups of waste packages will be assayed. The destructive analyses will consist of ashing or leaching of the waste material used for NDA, followed by radiochemical analysis. The results obtained from the NDA and destructive analyses of REDC waste will be analyzed and a determination will be made as to whether the capabilities exist to meet the requirements for identifying the REDC waste as TRU or non-TRU (by the end of FY 1996). This project plan also describes the project management, quality assurance, scheduling, and cost aspects of the project. 


\subsection{INTRODUCTION}

The introduction of a number of regulatory-based drivers have imposed more stringent requirements on the characterization of radioactive waste $[1,2,3]$. For transuranic (TRU) waste $^{1}$, the Department of Energy's (DOE) Waste Isolation Pilot Plant (WIPP) requires, at a minimum, that the waste generator (a) provide methods for sampling and analyzing waste streams to establish an acceptable-knowledge baseline [4], (b) develop a recurring sampling plan that will assure that the data quality objectives can be met, and (c) calibrate and use nondestructive assay (NDA) instruments for certifying the waste, by bulk measurement, to the WIPP waste acceptance criteria (WAC). In order to meet these requirements, existing waste characterization methods must be tested, evaluated, improved, and ultimately approved by WIPP.

Along with the technical and compliance related issues, an important consideration in the identification of radioactive waste as low-level or TRU is cost. This is due to the highly disparate disposal costs for low-level waste versus TRU waste. Current estimates suggest that the disposal costs for TRU waste may be an order of magnitude more than that of low-level waste per unit volume. Thus, it is very critical - during the waste characterization process - that the radioactive waste is accurately identified as low-level or TRU to avoid any unnecessary cost penalties while assuring compliance with regulations.

This report provides the plan for a project that will address an investigation of very unique radioactive waste as being potentially TRU or low-level. The radioactive waste of interest is solid waste generated in Buildings 7920 and 7930 at the Radiochemical Engineering Development Center (REDC), located at Oak Ridge National Laboratory (ORNL). REDC has produced approximately $90 \%$ by volume of the historic (legacy) remote-handled $(\mathrm{RH})^{2} \mathrm{TRU}$ wastes generated at ORNL. REDC currently produces all of the RH-TRU waste being generated at ORNL. The solid radioactive waste from REDC is currently managed as TRU waste. However, based on process knowledge and existing REDC waste certification records, ${ }^{244} \mathrm{Cm}$ and ${ }^{252} \mathrm{Cf}$ are the only documented radionuclides present in most of the waste. Neither of these two radionuclides are listed as TRU in the most recent Oak Ridge Reservation waste acceptance criteria. Preliminary assessments indicate that other TRU waste radionuclides are present; however, it is not known whether the total concentration of the TRU nuclides are above the 100 nanocuries per gram (nCi/g) limit specified in DOE Order 5820.2A [5]. Considering the large

${ }^{1}$ From DOE Order $5820.2 \mathrm{~A}$, TRU wastes are defined as those containing alpha emitting transuranium radionuclides with half-lives greater than 20 years and concentrations greater than $100 \mathrm{nCi} / \mathrm{g}$ at the time of assay. In 1991, ORNL petitioned DOE-Oak Ridge Operations (ORO) to include ${ }^{244} \mathrm{Cm}$ and ${ }^{252} \mathrm{Cf}$ as TRU waste radionuclides, due to their uniqueness to ORNL waste management and concerns such as difficulty in assaying and the need for special handling associated with neutron emissions. To date DOE-ORO has not approved this request, yet ORNL has continued to manage this waste as TRU.

${ }^{2}$ All TRU wastes generated at ORNL which have external contact dose rates greater than or equal to 200 $\mathrm{mrem} / \mathrm{hr}$ are classified as remote-handled (RH). Conversely, TRU wastes that have external contact dose rates less than $200 \mathrm{mrem} /$ hour are classified as contact-handled $(\mathrm{CH})$. 
inventory of REDC legacy waste, it is imperative that a correct determination be made regarding the classification of REDC wastes so that the ORNL waste management plan can be adapted accordingly.

The plan for this project consists of six tasks. In the first task, a pilot study will be performed to study in detail the isotopic makeup of the waste generated by REDC. This task involves statistical sampling (of smears and leached radioactivity) and radiochemical analysis. The second task will be to perform destructive, nondestructive and statistical analysis of actual REDC waste buckets containing melted polyethylene bottles, and to prepare a report. The third task will be to perform destructive, nondestructive and statistical analysis of REDC waste buckets containing leached non-combustible waste. The fourth task will be to design, prepare, and analyze a REDC spiked bucket. The spiked bucket will consist of bottled radioactive solutions which will serve as mock-ups of REDC waste. Some of the buckets of actual waste will eventually be destructively analyzed and the spiked buckets will be used as in-turn as calibration sources. The fifth task will be to correlate NDA measured radionuclides with TRU radionuclides. The final task will be to prepare a REDC waste characterization report. Note that the ultimate goal of these tasks is to provide technically sound REDC waste characterization data to enable shipments to WIPP for legacy and newly generated TRU wastes (CH \& RH).

The requirements that apply to this project are as follows:

(1) DOE Order 5820.2A requires that all newly generated waste be characterized and certified as the waste is being generated to avoid adding to the legacy waste stockpile.

(2) The TRUPACT-II Certificate of Compliance requires all TRU-contaminated wastes be handled as TRU waste unless it can be demonstrated with $95 \%$ confidence that the mean TRU concentration is less than $100 \mathrm{nCi} / \mathrm{g}$ of waste.

(3) TRU waste bound for disposal at the WIPP must meet WIPP packaging and WAC requirements.

(4) Accuracy and precision of waste characterization data must meet the specifications of the WIPP Transuranic Waste Characterization Quality Assurance Program Plan (WIPP QAPP) [1].

The goals of the project are to:

(1) Identify all isotopes of the waste stream, particularly TRU.

(2) Provide a baseline statement on the likelihood of the waste being TRU or not.

(3) Identify improvements to sampling, radiochemical analysis, and acceptable knowledge protocol, to meet WIPP requirements. 
(4) Calibrate existing NDA systems with actual REDC waste characterization data and identify potential improvements to existing bulk waste measurement systems so that waste certification is performed to prescribed Data Quality Objectives (DQO) in Table 9.1 of the WIPP QAPP. 


\subsection{BACKGROUND}

\subsection{Description of the REDC}

The REDC, which consists of ORNL buildings 7920 and 7930, is a generator of unique radioactive waste. Approximately $90 \%$ by volume of the legacy RH-TRU wastes stored at ORNL since 1970 are from the REDC. REDC newly generated waste represents $100 \%$ of the current ORNL RH-TRU inventory. REDC facilities are used for the production, storage, and distribution of radioactive heavy elements. These facilities recover and purify transplutonium elements: Americium through Fermium from targets irradiated in the High Flux Isotopes Reactor (HFIR) or in the Savannah River Plant (SRP) reactors. Transplutonium radioisotopes, particularly ${ }^{252} \mathrm{Cf}$, are produced for use in medical and industrial applications, for research on the properties of heavy elements, and for production of super-heavy elements (i.e., atomic numbers beyond 104). Building 7920 contains nine heavily shielded hot cells which houses equipment for high-radiation level radiochemical processing and target fabrication activities. In addition, this building is equipped with eight laboratories that are used for process development, processcontrol analyses, and final transuranium-element product purification and packaging operation.

\subsection{REDC Waste Handling Process Description}

According to the REDC Generator Certification Official (GCO), all REDC RH solid wastes are generated from its hot cells (referred to as cubicles). Based on data from the ORNL Waste Tracking System database ${ }^{3}$, approximately half of the $\mathrm{CH}$ wastes from REDC originate from the hot cells. The other half is generated by the REDC laboratories.

Large waste items from the cubicles, such as discarded equipment racks and heaters are removed as single units through the cubicle roof via an equipment transfer case. These discarded items are placed directly into a concrete cask without being packaged in an intermediate container.

Small solid waste items generated from each of the hot cells are transported via an inter-cell conveyor to a cubicle (Cubicle 9) for temporary storage. As Cubicle 9 becomes full, these waste items are repacked into intermediate receptacles such as paint cans, polyethylene (poly) buckets, and polyethylene bags. These receptacles, or packages (as they are commonly referred to), are then placed in a stainless-steel 55-gallon drum or concrete cask for disposal. The decision as to whether a drum or cask is used is based on dose rate measurements of the packages (i.e., cans, buckets, bags). Only the small waste items will be considered in this project.

3 The Waste Tracking System database is maintained by the ORNL Waste Management and Remedial Action Division (WMRAD) Document Management Center (DMC). 


\subsection{Preliminary Assessment of REDC Solid Waste Stream}

\subsubsection{Physical Description of the REDC Waste}

Remote-handled wastes from REDC consist primarily of sundry hot cell wastes and debris, High Efficiency Particulate Air (HEPA) filters from off-gas cleanup systems, and discarded equipment. The typical small items in the REDC wastes can be categorized as shown in Table 2.1.

The waste percentages by volume assigned for plastic, and glass were calculated based on the number of poly buckets containing paint pails of melted poly bottles ${ }^{4}$, sections of hot cell manipulator boots, and glass sample bottles listed in the waste inventory records for 2 casks: $\mathrm{X} 10 \mathrm{C} 930003$, and X10C 93023 . These two casks represent $50 \%$ of the waste inventory for a typical campaign and contain small waste items generated from Campaign $69^{5}$ which were recently transferred to the Waste Management and Remedial Action Division (WMRAD) for storage.

Table 2.1 Categorization of REDC Solid Wastes

\begin{tabular}{|c|l|c|}
\hline Waste type & \multicolumn{1}{|c|}{ Waste items } & Volume \\
\hline Plastic & $\begin{array}{l}\text { Melted poly bottles, poly blocks, } \\
\text { manipulator boots, tubing }\end{array}$ & $39 \%$ \\
\hline Glass & $\begin{array}{l}\text { Sample bottles, darkened or } \\
\text { broken glassware }\end{array}$ & $30 \%$ \\
\hline Metals & Tools, valve parts & $21 \%$ \\
\hline Cellulose & Cloth wipes, string, paper, wood & $10 \%$ \\
\hline
\end{tabular}

The final volume percentage for each waste category is then adjusted by the GCO to accurately reflect the percentage of metal and cloth wastes processed.

According to REDC personnel, large solid waste items are generally disposed after every four campaigns. Reference 6 indicated that the equipment racks are made of metal and they occupy approximately $90 \%$ of a cask volume. The percentage of plastic, glass, paper and cloth for the

${ }^{4}$ The paint pails sometimes contain pieces of metal and non-fusible plastic bottle caps, as well as polyethylene bottles and polypropylene filters.

${ }^{5}$ The REDC operations are carried out in phases called "campaigns." Each campaign may span over a duration of 12 to 18 months. 
remaining portion of the cask are $5 \%, 3 \%$, and $2 \%$, respectively. Waste samples will not be taken for this type of waste, since equipment racks are not disposed in the current campaign. 


\subsubsection{Radiological Profile of the Waste Stream}

Table 2.2 is a compilation of isotopes expected to be analyzed for in the REDC waste stream. This table was constructed on the basis of known burnup calculations [7]. In addition, a memorandum described additional isotopes from the REDC waste stream [8].

Table 2.2 List of Potential Radionuclides Present in REDC TRU Solid Wastes

\begin{tabular}{|c|c|}
\hline Alpha Decay Radionuclides ${ }^{\dagger}$ & Beta Decay Radionuclides ${ }^{\dagger}$ \\
\hline${ }^{242} \mathrm{Cm}$ & ${ }^{134} \mathrm{Cs}$ \\
\hline${ }^{243} \mathrm{Cm}$ & ${ }^{136} \mathrm{Cs}$ \\
\hline${ }^{244} \mathrm{Cm}$ & ${ }^{137} \mathrm{Cs}$ \\
\hline${ }^{245} \mathrm{Cm}$ & ${ }^{249} \mathrm{BK}$ \\
\hline${ }^{246} \mathrm{Cm}$ & ${ }^{152} \mathrm{Eu}$ \\
\hline${ }^{248} \mathrm{Cm}$ & ${ }^{154} \mathrm{Eu}$ \\
\hline${ }^{249} \mathrm{Cf}$ & ${ }^{155} \mathrm{Eu}$ \\
\hline${ }^{250} \mathrm{Cf}$ & ${ }^{147} \mathrm{Pm}$ \\
\hline${ }^{252} \mathrm{Cf}$ & ${ }^{63} \mathrm{Ni}$ \\
\hline${ }^{253} \mathrm{Cf}$ & $\overline{{ }^{55} \mathrm{Fe}}$ \\
\hline${ }^{227} \mathrm{Ac}$ & ${ }^{60} \mathrm{Co}$ \\
\hline${ }^{241} \mathrm{Am}$ & ${ }^{129} \mathrm{I}$ \\
\hline${ }^{242 \mathrm{~m}} \mathrm{Am}$ & ${ }^{99} \mathrm{Tc}$ \\
\hline${ }^{243} \mathrm{Am}$ & ${ }^{151} \mathrm{Sm}$ \\
\hline${ }^{226} \mathrm{Ra}^{*}$ & ${ }^{90} \mathrm{Sr}$ \\
\hline${ }^{228} \mathrm{Th}^{*}$ & ${ }^{90} \mathrm{Y}$ \\
\hline${ }^{229} \mathrm{Th}^{*}$ & ${ }^{125} \mathrm{Sb}$ \\
\hline${ }^{232} \mathrm{Th}^{*}$ & ${ }^{106} \mathrm{Ru}$ \\
\hline${ }^{238} \mathrm{Pu}$ & ${ }^{106} \mathrm{Rh}$ \\
\hline${ }^{239} \mathrm{Pu}$ & ${ }^{144} \mathrm{Ce}$ \\
\hline${ }^{240} \mathrm{Pu}$ & ${ }^{144} \mathrm{Pr}$ \\
\hline${ }^{242} \mathrm{Pu}$ & \\
\hline
\end{tabular}

Primary mode of decay

These radionuclides are not expected in REDC wastes since radium targets are not currently processed at REDC.

Note: ${ }^{233} \mathrm{U},{ }^{234} \mathrm{U},{ }^{235} \mathrm{U},{ }^{236} \mathrm{U},{ }^{238} \mathrm{U}$ are not expected in REDC wastes. 


\subsection{APPROACH}

The scope of this project is to perform an assessment of existing REDC waste characterization methods, and evaluate historical data and to collect samples of newly generated REDC wastes for analysis (if needed) to determine if legacy REDC wastes are TRU.

Presently, there is insufficient historical data available for determining whether the REDC solid wastes can be classified as TRU wastes. In order to make this determination, sampling and analysis of the waste stream and measurements of actual REDC solid wastes must be made. The sampling and analysis of the waste stream will be carried out in a pilot study. The objectives of the pilot study are to: (a) examine distribution of alpha and beta decay radionuclides among typical waste items being stored in REDC hot cells, (b) identify the typical distribution of alpha and gamma emitting radionuclides in the REDC hot cells (with special emphasis on TRU radionuclides), (c) provide sufficient data for the development of an appropriate sampling design or plan for NDA of REDC waste, and (d) validate the assumption of REDC staff that the ratios of isotopes within each radioactive element (i.e., curium, californium, and plutonium) remain relatively constant within a High Flux Isotope Reactor (HFIR) target campaign ${ }^{6}$. The first three objectives will be achieved by collecting smear and leached samples. From the radiochemical analysis of these samples, the variability of and association between the activities of the alpha and beta decay radionuclides of interest will be evaluated. To meet the last objective, the isotopic ratios determined from sampling and analysis will be compared against results from computer model predictions of radionuclide content in the HFIR targets and mass balance calculations for the REDC processes. From the information and data generated by the pilot study, it is anticipated that a better understanding of the waste isotopic profile will help in the calibration of NDA systems for measurements of actual waste and reduce the costs of the NDA portion of the project.

To perform measurements of the REDC solid or debris wastes, two approaches can be taken: NDA (supplemented with radiochemical analyses and mass spectrometry) and destructive assay alone. There are pros and cons associated with each method. With destructive assay, the actual measurement of samples can provide accurate results; however, the sampling errors that arise from taking a number of samples, particularly from heterogeneous waste, can be large and impossible to estimate. The REDC solid waste stream is not only heterogenous, but is very radioactive as well. The high dose rates involved make it difficult (from an ALARA standpoint) to perform sampling of the waste containers. The onerous task of opening legacy waste containers for sampling can be avoided by using the bulk measurement approach used in NDA (for the $\mathrm{CH}$ waste drums). However, it has not been demonstrated that the existing ORNL NDA systems, which are optimized for assaying $\mathrm{CH}$-weapons grade plutonium, can adequately discriminate between TRU and non-TRU wastes in the presence of interfering radiation from non-TRU radionuclides (e.g. ${ }^{244} \mathrm{Cm}$ and ${ }^{252} \mathrm{Cf}$ ), particularly with the level of confidence specified in the WIPP QAPP [1]. Testing, evaluating, and engineering of current NDA systems must be

\footnotetext{
${ }^{6}$ Campaign 69 was completed in early 1996. Campaign 70 material is being processed.
} 
performed for the purpose of ORNL TRU waste characterization.

For this project, NDA and destructive assay will be performed on selected packages of newly generated $\mathrm{CH}$ waste from Building 7920 of the $\mathrm{REDC}^{7}$. Newly generated waste, rather than legacy waste will be studied for several reasons. Among the major concerns with handling the legacy waste are the high dose rates, the high potential for alpha contamination when legacy waste containers are opened to collect samples, and the deteriorated state of the legacy waste packages. Coupled with the poor or in some cases, lack of, documentation on the legacy waste, it is considered that using newly generated $\mathrm{CH}$ waste is consistent with the principle of ALARA. Other reasons for using $\mathrm{CH}$ waste are based on the fact that the Waste Examination and Assay Facility (WEAF), where the NDA systems are located, has facility limits that only allow for $\mathrm{CH}$ waste packages to be brought into the facility. Additionally, there are existing technical limitations imposed by the assay equipment. Current systems have been calibrated and successfully used for low dose rate 55-gallon drums containing primarily weapons grade plutonium $[9,10,11]$. Neutron coincidence counting and the differential dieaway methods become more difficult as the dose rate increases, but have been shown to be feasible for ORNL RH-TRU waste assay $[12,13,14]$. For bulk gamma-ray measurements, the system needs to be adjusted to handle large gamma dose rates. Additionally, consideration will be given to detector damage caused by large neutron fluence rates. Finally, using newly generated waste with surface dose rates more consistent with ALARA principles makes it easier to handle the packages under test conditions.

7 The waste from Building 7920 is more complex than the waste from Building 7930 . Hence, this project will focus on the waste from Building 7920. The waste from Building 7930 is being independently characterized. 


\subsection{PILOT STUDY}

\subsection{Task Scope}

This task directly supports the calibration of NDA instrumentation used to characterize REDC legacy and newly-generated waste. Since the current NDA systems cannot separate TRU from non-TRU radionuclides with the necessary accuracy, an isotopic profile of the REDC waste (including gamma and beta emitters, such as ${ }^{237} \mathrm{~Np}$ ) must be established. These data will be used to determine the relationship between TRU and non-TRU radionuclides and, thus, provide as complete a characterization of REDC waste as possible.

The isotopic profile determined by sampling and analysis will be used to adjust the relative fissile material response (active) and the spontaneous fission rate (passive) of the APNEA system. Similarly, the profile will be used to make inferences about the transuranic gamma-ray signal in the presence of strong interferences from fission and activation products. NDA systems are most effective when the isotopic ratios are known a priori. The gamma-ray system is used to confirm that the ratios are nominal. The APNEA system is used to measure fissile material.

\subsection{Method for Sampling and Analysis}

Smear samples will be taken from the surface of different components of REDC hot cell waste, e.g., plastic, glass, metal, etc. The smears are Q-tip swabs with wooden handles. After a smear is taken, the Q-tip head will be placed in a pre-labeled sample bottle. The extra wood on the Qtip swab will be broken off to avoid cross-contamination from the manipulator fingers or other sources. The sample bottle will then be capped and removed from the hot cell.

Originally, it was desired that the smear samples would be representative of the entire surface contamination of the given object (e.g., poly buckets, lower arm segments of the hot cell manipulator boots). This was proven to be not possible and deemed unnecessary [10]. Hence, smears will be taken from waste buckets, the top of the poly melts, the interior and thread areas of poly bottles, holes in poly valves, along light cords, the cuff areas of hot cell manipulator boots, bottle lids (including the threads), leached glass sample bottles (inside and out), the surface of filter housings, metal tools, and cloth wipes.

Gamma and neutron dose rates will be taken (outside the hot cells using portable survey instruments) for each smear sample to ensure that the total gamma plus neutron dose rate does not exceed $50 \mathrm{mrem} / \mathrm{hr}$ per sample. A further check will also be made to ensure that the neutron dose rate per sample does not exceed $10 \mathrm{mrem} / \mathrm{hr}$. This dose rate check is done to prevent damage to analytical equipment and also to minimize personnel exposure. The smear samples will then be analyzed in a radiochemical laboratory using gross neutron, gross alpha, alpha pulse height analysis, and gamma spectrometry.

Leached samples will be collected from polyethylene bottles (before they are melted) and glass 
wastes. Mass spectrometry will be performed on the leached samples to establish the radionuclide profile. As with the smears, gross neutron, gross alpha, alpha pulse height analysis, and gamma spectrometry will also be performed. The results from the smear and leached samples will be compared to examine the effectiveness of each sampling technique.

\subsection{Analysis of the Sampling Results}

From each smear sample, the following information will be recorded: (a) waste cell source, (b) waste component class, (c) individual alpha activities $(\mathrm{Bq} / \mathrm{total})$ of the radionuclides ${ }^{244} \mathrm{Cm},{ }^{238} \mathrm{Pu}$, ${ }^{239 / 240} \mathrm{Pu},{ }^{241} \mathrm{Am},{ }^{243} \mathrm{Am},{ }^{252} \mathrm{Cf},{ }^{242} \mathrm{Cm}$, and ${ }^{246} \mathrm{Cm}$, and (d) the gross alpha activity. In addition, from the available data, radionuclide ratios will also be calculated and evaluated for consistency across the various waste types (e.g., glass, plastic, metal, etc. $)^{8}$.

Using the Pilot Study data, analyses will be performed to generate summary statistics for the data set, e.g., estimate the isotopic activities and derive standard errors for the observed activities.

Once the radionuclide activities are estimated for the individual samples, the following analyses will be done:

(1) Within each waste component type, the radionuclide ratios [(radionuclide activity)/(gross alpha activity)] will be obtained for each sample. Comparisons will be made to determine if these ratios change significantly from one waste type to another. From the multiple independent samples within each waste type, estimates of the magnitude of the sample-to-sample variability of these ratios within each waste type can also be obtained.

(2) Within each waste component type, associations or correlations between the TRU activity and the activities of the other radionuclides or groups of radionuclides (e.g., ${ }^{244} \mathrm{Cm},{ }^{252} \mathrm{Cf}$, etc.) will be examined. If there is a significant correlation, then it can be used to predict the TRU activity from these other radionuclide activities. Tests will also be done to determine if this association or correlation changes significantly from one waste type to another.

(3) Modifications will be made to the statistical analysis to account for the presence of observed activities below analytical method detection limits.

(4) Using the Pilot Study data set, QA/QC requirements for determining the number of samples required to satisfy the concept of representative sampling will be established.

${ }^{8} \mathrm{~A}$ weakness of the present and past record keeping is the inaccurate data for weights of each type of physical waste. Even if radioisotope levels are known and related to waste types, the aggregate result will not be accurate. It may be necessary to relate activity to total waste weight only. Accurate package weight data are lacking; it will be necessary to weigh each drum of $\mathrm{CH}$ waste. 


\subsection{Pilot Study Task Summary and Reporting of Results}

This tasks that will be conducted under the Pilot Study are summarized as follows:

(1) Measure and report isotopic ratios of TRU radionuclides and ${ }^{252} \mathrm{Cf}$ to gross alpha activity.

(2) Test whether the ratios are constant over different types of debris waste or whether it is necessary to pool activity or pool weight to obtain general concentrations.

(3) Assist in the calibration of nondestructive assay instruments, including the resolution of $(\alpha, n)$ reactions in high neutron background.

(4) Establish a basis for ascertaining whether the concentration of all TRU radionuclides in a drum is less than the $100 \mathrm{nCi} / \mathrm{g}$ limit for classification as low-level waste.

Once the results from the pilot study have been analyzed statistically, a technical report will be prepared and published. 
This section describes two separate analytical approaches for quantifying the isotopes found in bulk REDC waste: NDA and destructive assay. In the case of NDA, radiation emitted from the radioactive waste in bulk is measured directly to quantify the constituent isotopes. In the case of destructive assay, the waste form is physically treated in such a way that the isotopes are either separated from the bulk material or the material is reduced to a homogeneous solid or liquid with the isotopes evenly distributed throughout, thereby reducing the waste to a sampleable form.

In addition to the overviews on NDA and destructive assay, the tasks associated with the primary characterization of REDC CH-TRU waste will be described. These tasks directly support the calibration of NDA instrumentation used to characterize REDC legacy and newly-generated waste. A direct comparison between destructive and nondestructive assays combined with a thorough statistical analysis of the results will provide a basis upon which future NDA measurements of REDC waste will be technically sound and defensible.

\subsection{Nondestructive Assay and Examination}

NDA has been applied successfully throughout the DOE complex for waste bearing weapons grade plutonium and low-activity wastes containing fission and activation products. At ORNL, 822 55-gal drums of transuranic waste were received from Nuclear Fuel Services, all of which underwent NDA for verification that the isotope quantities met the existing WIPP WAC [3]. NDA offers a relatively inexpensive means of accurate isotope quantification while preserving extremely sound radiological safety practice; drums of waste are not opened, processed, or treated; thereby, reducing the dose to radiation workers to less than $100 \mathrm{mrem} / \mathrm{yr}$. To make the most accurate measurements, NDA instruments must be calibrated for specific waste streams. In many cases, a recalibration is nothing more than determining efficiency corrections for the geometry, isotopes, and bulk material effects on the measured signal. In highly specialized cases, the instruments should be re-engineered to meet specific measurement demands. The unique nature of REDC waste and the fact that the most predominant isotopes are not transuranic-waste makes this project a highly specialized case [5].

In order to adapt the NDA instruments at the WEAF to meet the TRU waste characterization requirements and determine which REDC wastes are TRU and which are non-TRU and provide quantative assay data, several steps must be taken. First, actual waste from the REDC must be assayed using NDA methods to evaluate the instrument response. Once this is done, adjustments can then be made to the NDA equipment as necessary to determine if the measurements can be performed adequately. To this end, waste drums must be assembled with packages ${ }^{9}$ containing waste representative of a REDC campaign. The buckets are used as disposal containers for small $\mathrm{CH}$ waste objects from the REDC hot cells. The waste items that will be collected for the NDA

\footnotetext{
${ }^{9}$ Double-bagged plastic seal-out buckets. Some contain paint pails with melted poly, or small metal or glass items.
} 
portion of this project will originate from the current REDC campaign, Campaign 69 . Aside from the criterion that the wastes used for NDA system evaluation be representative of REDC hot cell wastes, care must be taken to limit the dose rates so that the buckets can be handled according to ALARA principles and the current NDA system capabilities are not exceeded. As mentioned earlier, the APNEA system used for neutron assay is optimized for measurements of weapons grade plutonium and has not been adjusted to handle excessive gamma and neutron dose rates. For example, the Nuclear Fuel Services waste - weapons grade plutonium - measured on contact, an average of about $2 \mathrm{mrem} / \mathrm{hr}$ gamma and less than $0.5 \mathrm{mrem} / \mathrm{hr}$ neutron. Maximum dose rates were just $40 \mathrm{mrem} / \mathrm{hr}$ and $0.8 \mathrm{mrem} / \mathrm{hr}$, gamma and neutron, respectively. In the case of REDC-generated waste the gamma and neutron dose rates are nearly the same, ranging anywhere from $50 \mathrm{mrem} / \mathrm{hr}$ (each) up to the rem $/ \mathrm{hr}$ range. When the neutron dose rate is over $30-40 \mathrm{mrem} / \mathrm{hr}$, the total neutron production rate is in the range of a million neutrons per second. The APNEA detector packages and electronics were not originally designed to accomodate this large a neutron fluence rate. In addition to the buckets of actual REDC waste, mock-up buckets of clean polyethylene will be fabricated to study matrix effects. Polyethylene blocks will be melted in metal buckets to simulate the buckets of melted polyethylene wastes.

After completing the NDA analysis, the buckets of REDC waste will be destructively analyzed. This step will provide more information on the actual radionuclide content in the waste. The data gathered from the destructive assay of the previously nondestructively assayed waste will be used to support the recalibration and re-engineering of the NDA systems. Since the destructive assay phase will effectively destroy the waste buckets used for the NDA system studies, a "spiked" bucket will be fabricated to provide a transitional (or "transfer") source for calibration purposes. This "spiked" bucket will contain bottles containing radioactive solutions. The radioactive solutions will be prepared such that they represent the radioactive make-up of the actual REDC CH wastes, both in terms of radionuclide types and concentrations. In the course of performing the NDA system evaluations, experimental design and analysis methods will be used to ensure that the results meet the required levels of statistical rigor. Analytical test methods will be developed to ensure the quality of data in terms of accuracy and precision. Calibration experiments will also be designed to ensure that NDA results can be achieved with the required levels of confidence.

\subsection{Destructive Radiological Analyses}

Destructive assay of the contents of the poly buckets used in the NDA will be performed in order to obtain more information on the radionuclides present in the waste. At this point in time, the two approaches being considered for obtaining homogeneous samples for destructive assay are leaching of non-combustible waste (e.g., metals and glass) and ashing of combustible wastes (e.g., polymelts, cloth).

Once the leaching and/or ashing has been performed, aliquot samples will be taken from the leachate or ash. The samples collected are subjected to routine radiochemical processing and analysis (i.e., precipitation and separation followed by alpha and/or gamma spectrometry). The 
sample activities are then used to determine the original batch TRU activities and radionuclide percentages for comparison with NDA results.

In general, destructive radiological analyses include gross alpha counting, alpha pulse height analysis, mass spectrometry analysis, and gamma spectrometry. Gross alpha counting is used to determine the total activity in the sample. Alpha pulse height analysis provides the percentage of activity contributed by each alpha emitter detected in the sample. Mass spectrometry analysis provides the isotopic percentage distribution of a particular radionuclide in the sample.

Radium and thorium isotopes were present in RH-TRU solid waste packaged in October 1984. Based on process knowledge, these radionuclides were associated with the processing of radium targets at REDC. Radium targets are no longer processed at the present time. REDC RH-TRU solid wastes do not contain any uranium isotopes. On occasion, the analytical laboratories in Building 7920 of REDC will work on various samples taken from other laboratories. These nuclides are not co-mingled with REDC hot cell wastes. Table 5.1 provides a list of the analytical methods that can be used to confirm the presence of suspect radionuclides present in REDC waste.

Table 5.1 Analytical Test Methods

\begin{tabular}{|l|l|}
\hline \multicolumn{1}{|c|}{ Test Method } & \multicolumn{1}{|c|}{ Nuclides Analyzed } \\
\hline $\begin{array}{l}\text { Gross alpha, alpha spectrometry, gamma } \\
\text { spectrometry, gross neutron }\end{array}$ & ${ }^{244} \mathrm{Cm},{ }^{252} \mathrm{Cf},{ }^{241} \mathrm{Am},{ }^{134} \mathrm{Cs},{ }^{136} \mathrm{Cs},{ }^{154} \mathrm{Eu},{ }^{155} \mathrm{Eu}$, \\
\hline $\begin{array}{l}{ }^{237} \mathrm{~Np},{ }^{95} \mathrm{Nb},{ }^{25} \mathrm{Sb},{ }^{253} \mathrm{Es},{ }^{226} \mathrm{Ra},{ }^{228} \mathrm{Th}, \\
\text { (TIMS), Pu separation }\end{array}$ & ${ }^{229} \mathrm{Th},{ }^{106} \mathrm{Ru},{ }^{144} \mathrm{Ce},{ }^{144} \mathrm{Pr}$ \\
\hline TIMS, Cm separation & ${ }^{238} \mathrm{Pu},{ }^{239} \mathrm{Pu},{ }^{240} \mathrm{Pu},{ }^{242} \mathrm{Pu}$ \\
\hline TIMS, Am separation & ${ }^{242} \mathrm{Cm},{ }^{243} \mathrm{Cm},{ }^{244} \mathrm{Cm},{ }^{245} \mathrm{Cm},{ }^{246} \mathrm{Cm},{ }^{248} \mathrm{Cm}$ \\
\hline $\begin{array}{l}\text { Cf High Performance Liquid Chromatography } \\
\text { separation, TIMS }\end{array}$ & ${ }^{241} \mathrm{Am},{ }^{242} \mathrm{Am},{ }^{250} \mathrm{Cf},{ }^{252} \mathrm{Cf},{ }^{253} \mathrm{Cf}$ \\
\hline Sr separation & ${ }^{90} \mathrm{Sr},{ }^{90} \mathrm{Y}$ \\
\hline Tc separation & ${ }^{99} \mathrm{Tc}$ \\
\hline Bk separation & ${ }^{249} \mathrm{Bk}$ \\
\hline $\begin{array}{l}\text { ICP-AES, Th separation, ICP-Mass } \\
\text { Spectrometry (MS) }\end{array}$ & ${ }^{228} \mathrm{Th},{ }^{229} \mathrm{Th},{ }^{232} \mathrm{Th}$ \\
\hline Elemental separations followed by ICP-MS & ${ }^{63} \mathrm{Ni},{ }^{227} \mathrm{Ac}$ \\
\hline
\end{tabular}

Typically, ${ }^{244} \mathrm{Cm}$ contributes the most alpha activity present in the REDC solid waste stream. It 
is difficult to analyze for other heavy curium isotopes (such as ${ }^{242} \mathrm{Cm},{ }^{246} \mathrm{Cm}$, and ${ }^{248} \mathrm{Cm}$ ) by alpha pulse height analysis in the presence of ${ }^{244} \mathrm{Cm}$. This problem can be overcome by performing mass spectrometry analysis on the curium radionuclides. Based on material balances and process knowledge, REDC personnel have speculated that the ratio of curium isotopes will not change during each campaign performed at REDC. This hypothesis, and its extension to include the isotopes of californium and plutonium, will be tested by the pilot study.

At the start of each campaign, the isotopic ratio for curium, californium, (and plutonium if Mark42 targets are processed) are estimated based on the feed materials and the concentrations of the "rework" stream. As the campaign progresses, samples are collected for mass spectrometry analysis. The results of the mass spectrometry analysis is then used to determine the isotopic ratios of the curium, californium, and/or plutonium present in the various feed/product streams generated during the campaign.

\subsection{NDA and Desctructive Assay Tasks}

\subsubsection{Perform Analysis of REDC Polyethylene Buckets}

A number of REDC buckets containing pails of melted polyethylene bottles will be assayed using NDA instruments (APNEA and Gamma Assay Segmented Passive [GASP] Systems) at the WEAF. Buckets will subsequently be ashed and radiochemically analyzed. Activity ratios of TRU radionuclide alpha counts to gross alpha, to ${ }^{244} \mathrm{Cm}$, and to ${ }^{252} \mathrm{Cf}$ will be determined. The relationship between TRU elements and gamma-beta emitters will be added to the task. The statistical analysis of the destructive assay results will then be used to assist in the calibration of NDA systems with the expressed goal of providing a more accurate estimate of the amount of TRU material present in a REDC legacy and newly-generated wastes.

\subsubsection{Perform Analysis of REDC Non-combustible Buckets}

Destructive, nondestructive, and statistical analysis of leached REDC waste buckets containing non-combustible waste will be performed. The data obtained in this study will provide essential NDA calibration points for a large percentage of REDC wastes (approximately $50 \%$ of REDC waste is non-combustible) and, even more importantly, it will also serve as a destructive assay validation of NDA by providing independent data which can then be compared to NDA assay results. This study will also serve as a measure of the effectiveness of leaching REDC waste in possibly reducing activity levels and, thereby, making it possible to reclassify the waste as LLW. The results of this analysis will also be incorporated into the design and analysis of a spiked bucket. The spiked bucket in this case is a bucket containing a pail of melted poly and bottled radioactive solutions

This task will be accomplished by performing NDA on two REDC waste buckets containing actual waste (in melted poly form). In addition, two REDC buckets containing non-combustible 
waste will be leached and the leachate radiochemically analyzed. The residual activity remaining on the leachant will be determined using portable health physics instrumentation to provide a preliminary estimate of effectiveness of the leaching procedure. After the leaching procedure has been accomplished, NDA will be performed on the REDC buckets to more accurately determine the effectiveness of the leaching technique. Both NDA and destructive assay data will be analyzed to determine functional relationships between isotopic distribution data and destructive techniques.

\subsubsection{Design, Prepare, and Analyze REDC Spiked Bucket}

This task consists of the following steps: (1) design the spiked bucket (e.g., choosing combinations of levels of activity spikes and other factors); (2) fabricate spiked bucket; perform nondestructive analysis, statistically analyze the results; develop appropriate models (either physical models or empirical); (3) determining goodness of fit, estimation of uncertainty, comparison to WIPP QAPP, development of data fusion with pilot study results; and (4) determining appropriate uncertainty analysis and error propagation methods. These data will be essential in calibrating the NDA systems used to characterize REDC waste.

A design for preparing the spiked buckets will be developed based upon already acquired REDC NDA and radioanalytical data. The buckets will be nondestructively assayed using the WEAF's NDA instruments (APNea and GASP Systems). A statistical analysis of the NDA results as compared to the known values of the solutions used to spike the buckets will be performed.

\subsection{Correlate NDA Measured Radionuclides with TRU Radionuclides}

Preliminary evaluation of the pilot study data already collected from REDC hot cell wastes suggest a correlation exists between fission product and actinide concentrations. Given the current measurement capabilities at ORNL, GASP can be used to classify TRU waste only if such correlations have been established. The objectives of this task are to confirm if such a correlation exists and to provide an initial estimate of the initial TRU concentrations in REDC solid wastes with an associated uncertainty level. A computer model will be developed to estimate the REDC TRU inventory as a function of time. A report entitled, "Evaluation of Measurements of Fission Products for TRU Waste Characterization" will be prepared.

The activity ratios of all alpha-emitting radionuclides obtained from radiochemical analyses performed for the pilot study and those gamma-emitting radionuclides measurable using the GASP System will be calculated. Cumulative Distribution Function (CDF) plots will be generated to provide activity correlations between these two types of radionuclides. These correlations and the concentrations of measurable gamma-emitting radionuclides collected using the GASP will then be used to determine the initial concentrations of TRU radionuclides and/or fission products for input to a computer code, RADAC [16]. RADAC will use initial concentrations of these radionuclides and the correlations derived from the CDF plots to estimate the REDC TRU waste concentrations (with associated upper and lower confidence limits) as a function of time. Uncertainty analysis will be performed to compute the distribution of waste 
compositions that may be expected at various time intervals.

\subsection{REDC Waste Characterization Report}

A report on NDA, with incorporation of pilot study results and leached bucket analysis, will be written. The report will include a proof-of-principle report for NDA, written with input from REDC personnel. This is the final report and will require contributions from all members of the team to discuss their contributions and the results of their tasks. Among the many subcomponents is a summary of the findings, a compilation of the results from the studies conducted under the project, and conclusions. 


\subsection{PROJECT MANAGEMENT}

The goal of project management is to ensure that the activities carried out under this project are fully funded and are managed in a manner that ensures satisfactory achievement of the project objectives. Detailed project costs and resources needed have been estimated - this information is provided in Section 8 of this report. The project status and financial reports are being submitted as input to the DOE-OR Progress Tracking System (PTS) and also to the DOE National TRU Program (NTP) meeting. Project management activities include the following:

(1) Developing the cost estimates and spending plan for the project.

(2) Preparing task scope descriptions and other pertinent information to be included in the budget proposal submittals.

(3) Providing milestone status reports on a weekly basis and project financial updates on a monthly basis .

(4) Providing input to the performance indicator tracking system.

(5) Preparing meeting agendas and holding team meetings on a regular basis.

The project will be managed by a Project Manager matrixed to the TRU Program. The project participants will include technical staff and technicians from the Applied Radiation Measurements Department (ARMD) of the Waste Management and Remedial Action Division (WMRAD), a technical staff member from WMRAD, a technical staff member from the Chemical Analysis and Services Division (CASD), and statisticians from the Computer Science and Mathematics Division (CS\&MD). Technical oversight of the project will be provided by the TRU Program Technical Advisor. The project team members will be working closely with Chemical Technology Division (CTD) personnel at the REDC, not only to obtain samples of waste packages for the characterization effort, but also to acquire an appreciation of the process technology, waste treatment/packaging techniques, and a basis for interpreting and applying the analytical results. 
The general areas of responsibility for the project team are presented in Table 6.1.

Table 6.1 Project Responsibilities

\begin{tabular}{||l|l||}
\hline \multicolumn{1}{|c|}{ Activity } & \multicolumn{1}{c|}{ Responsibility } \\
\hline Project Management & TRU Program (ARMD) \\
\hline Pilot Study & TRU Program, CASD, CS\&MD \\
\hline NDA & ARMD \\
\hline Destructive Assay & TRU Program, CASD, CS\&MD \\
\hline Statistics & CS\&MD \\
\hline Data Evaluation & ARMD, CS\&MD \\
\hline Interpretation & REDC, all above \\
\hline
\end{tabular}




\subsection{QUALITY ASSURANCE}

All activities undertaken by organizations involved in executing the scope of this project must be controlled commensurate with the importance of the work that is being done.

Quality Assurance for the project will be based on the guidelines provided in the WMRAD Quality Management Plan [17], the Transuranic Waste Characterization Quality Assurance Program Plan [1], and the Quality Assurance Plan for Contact-Handled Transuranic Waste Certification and Operations [18]. 


\subsection{PROJECTED SCHEDULE AND COST}

\subsection{Planned Activities and Schedule}

The planned activities for Fiscal Year (FY) 1996 are:

(1) Perform REDC Waste Pilot Study.

(2) Perform Analysis of REDC Polyethylene Buckets.

(3) Perform Analysis of REDC Non-combustible Buckets.

(4) Design, Prepare, and Analyze REDC Spiked Bucket.

(5) Correlate NDA Measured Radionuclides with TRU Radionuclides.

(6) REDC Waste Characterization Report.

These activities numbered 2 to 5 above are shown in the FY 1996 project flowchart for NDA and destructive assay activities (Figure 8.1). The milestones associated with the FY 1996 activities are presented in Table 8.1. The schedule for the project is shown in a Gantt Chart in Figure 8.2.

Table 8.1 FY 1996 Milestones

\begin{tabular}{|l|l||}
\hline FY 1996 Milestones & Completion Dates \\
\hline $\begin{array}{l}\text { Complete the initial Project Plan for review } \\
\text { and approval }\end{array}$ & May 31, 1996 \\
\hline $\begin{array}{l}\text { Complete fabrication of a "blank" bucket and } \\
\text { collect } 1 \text { to } 2 \text { buckets of actual waste from } \\
\text { Campaign } 69\end{array}$ & June 30, 1996 \\
\hline \begin{tabular}{l} 
Complete NDA of Campaign 69 buckets \\
\hline $\begin{array}{l}\text { Determine whether the capability exists for } \\
\text { discriminating between TRU and non TRU } \\
\text { waste }\end{array}$
\end{tabular} & September 30, 1996 \\
\hline
\end{tabular}


Figure 8.1 FY 1996 Project Flowchart for NDA and Destructive Assay Activities

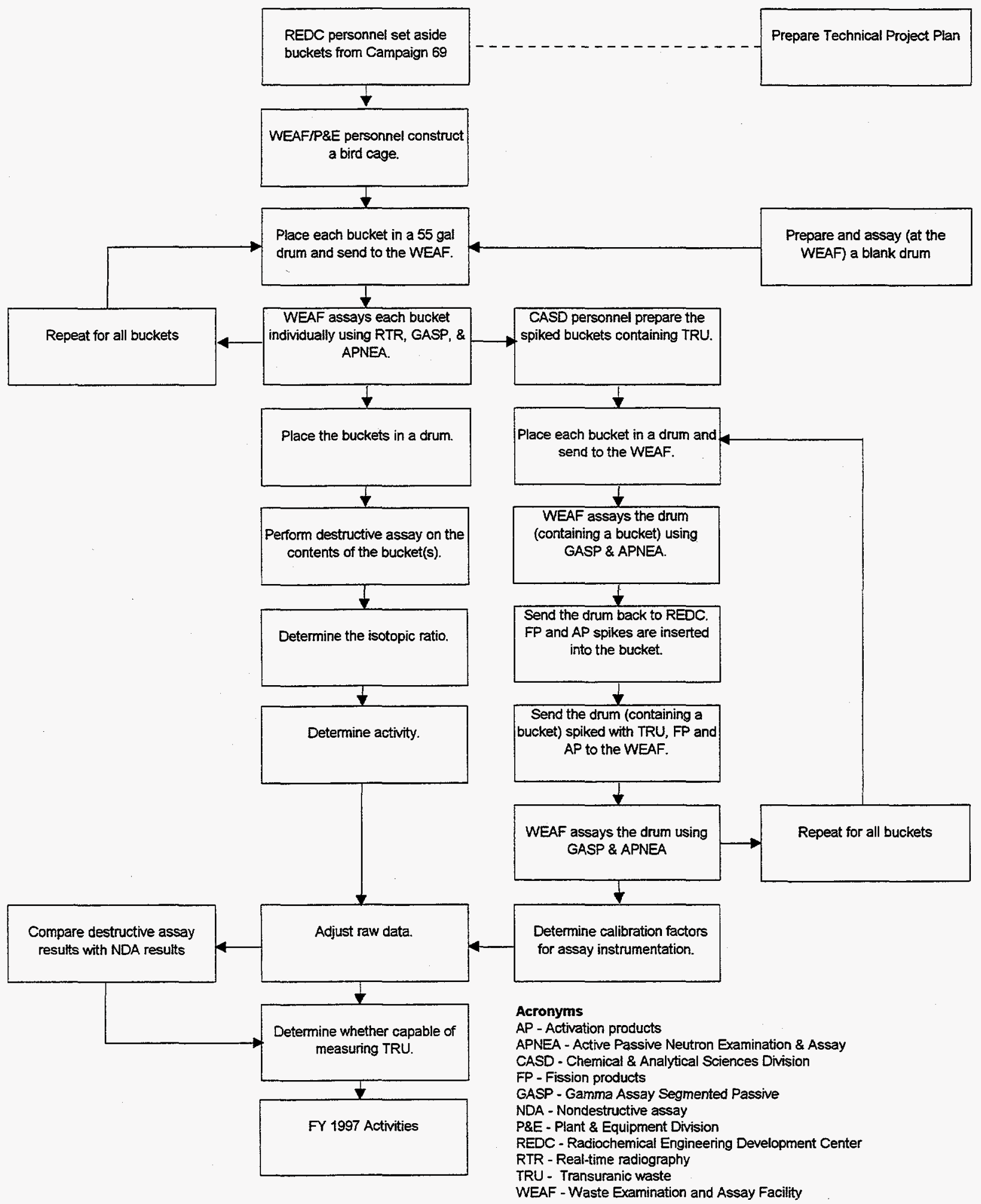

Key to activity groups

A - Preparation and nondestructive characterization of the Campaign 69 drum $B$ - Assay of blanks

C - Preparation and nondestructive characterization of the spiked drum

D - Destructive characterization of the Campaign 69 drum waste components

E - Analysis of characterization results

F - Preparation of a sampling plan

$G$ - Characterization of Campaign 69 drums. 
Figure 8.2 Planned Activities - FY 1996

\begin{tabular}{|c|c|c|c|c|c|c|c|c|c|}
\hline DESCRIPTION & $\begin{array}{r}\text { FY } 1996 \\
\text { Jan }\end{array}$ & Feb & Mar & Apr & May & Jun & Jul & Aug & Sep \\
\hline \multicolumn{10}{|l|}{ Preparation and NDA of C- 69 buckets } \\
\hline \multicolumn{10}{|l|}{ Prepare \& sign MOU between WMRAD and Chem Tech } \\
\hline \multicolumn{10}{|l|}{ Accumulate buckets } \\
\hline \multicolumn{10}{|l|}{ Assay buckets drums at the WEAF } \\
\hline \multicolumn{10}{|l|}{ Milestone 1. Project Plan TM ready for review \& approval } \\
\hline \multicolumn{10}{|l|}{ Milestone 3-Complete NDA of C- 69 buckets } \\
\hline \multicolumn{10}{|l|}{ Preparation and NDA of spiked buckets } \\
\hline \multicolumn{10}{|l|}{ Determine spike radionuclides and activities and bucket contents } \\
\hline \multicolumn{10}{|l|}{ Prepare spiked buckets } \\
\hline \multicolumn{10}{|l|}{ Milestone 2 - Report on Preparation of C-69 and Blank Buckets } \\
\hline \multicolumn{10}{|l|}{ Destructive Assay of C- 69 buckets } \\
\hline \multicolumn{10}{|l|}{ Leach and ash C- 69 buckets } \\
\hline \multicolumn{10}{|l|}{ Assay Blank (buckets \& drum) } \\
\hline \multicolumn{10}{|l|}{ Collect blank bucket components } \\
\hline \multicolumn{10}{|l|}{ Melt poly } \\
\hline \multicolumn{10}{|l|}{ Assay blank buckets } \\
\hline \multicolumn{10}{|l|}{ Final Data Analysis \& Prepare Report } \\
\hline \multicolumn{10}{|l|}{ Analyze data and prepare a report } \\
\hline \multicolumn{10}{|l|}{ Milestone 4 - A report on capability to discriminate between TRU and non-TRU } \\
\hline \multicolumn{10}{|l|}{ Prepare the Pilot Study Report } \\
\hline Prepare the Pilot Study Report & & & & & & & & & \\
\hline
\end{tabular}




\subsection{Project Cost}

The ORNL TRU waste characterization project is funded as a part of the technical support activities under the ORNL TRU program. Budget requests are prepared and tracked through the LMES Activity Data Sheet (ADS) system. The cost estimates for activities to be performed by individual ORNL divisions and subcontractors associated with this project for FY 1996 are presented in Table 8.2.

The costs associated with WMRAD, CS\&M, CASD, and subcontractor are for the provision of overall project support, to collect analytical data, to review NDA/destructive assay measurement data, to calibrate NDA systems against actual REDC wastes, and to validate NDA measurements against destructive assay results for determining whether REDC wastes can be classified as TRU wastes. CTD personnel from REDC will be used to assemble wastes packages for NDA measurements. In addition, CTD/REDC staff will collect samples and perform leaching of metal and glass waste types for radiochemical analysis. REDC staff will play a big role in interpretation/application of the experimental results.

Table 8.2 FY 1996 Projected Costs

\begin{tabular}{|c|c|}
\hline Organization & Cost \\
\hline ARMD & $\$ 160 \mathrm{~K}$ \\
\hline WMRAD & $\$ 150 \mathrm{~K}$ \\
\hline CS\&M & $\$ 180 \mathrm{~K}$ \\
\hline CASD & $\$ 80 \mathrm{~K}$ \\
\hline CTD & $\$ 5 \mathrm{~K}$ \\
\hline Total & $\$ 575 \mathrm{~K}$ \\
\hline
\end{tabular}




\section{REFERENCES}

1. Transuranic Waste Characterization Quality Assurance Program Plan, Rev. 0, CAO-941010, U.S. Department of Energy, Carlsbad, New Mexico, April 1995.

2. Waste Acceptance Criteria for the Oak Ridge Reservation, ES/WM-10, Energy Systems Waste Management Organization, Martin Marietta, Oak Ridge, Tennessee, July 1994.

3. TRU Waste Acceptance Criteria for the Waste Isolation Pilot Plant, WIPP-DOE-069, Rev. 5, U.S. Department of Energy, Washington D.C.

4. Review of the Final Draft Transuranic Waste Characterization Acceptable Knowledge Guidance Document, Department of Energy Memorandum, U.S. Department of Energy, Carlsbad, New Mexico, July 1995.

5. Radioactive Waste Management, DOE Order 5820.2A, U.S. Department of Energy, Washington D.C., September 1988.

6. Remote-Handled Transuranic Solid Waste Characterization Study: Oak Ridge National Laboratory, ORNL/TM-11050, R. C. Stewart et al., Oak Ridge National Laboratory, Oak Ridge, Tennessee, June 1989.

7. Estimated Radionuclide Content of the REDC LLW, Internal Correspondence from V. L. Fowler and T. E. Kent to J. S. Baldwin and J. H. Platfoot, Oak Ridge National Laboratory, Oak Ridge, Tennessee, May 1994.

8. Estimated Contents of Waste Containers, Intra-Laboratory Correspondence from J. E. Bigelow to T. Grizzard, Oak Ridge National Laboratory, Oak Ridge, Tennessee, October 1984.

9. DOE Assay Methods Used for Characterization of Contact-Handled Transuranic Waste, F. J. Schultz, J. T. Caldwell, , ORNL-6485, Oak Ridge National Laboratory, Oak Ridge, Tennessee, August 1991.

10. Source Imaging of Drums in the APNEA System, D. C. Hensley, CONF-951091, p. 85, Proceedings of the 4th Nondestructive Assay and Nondestructive Examination Waste Characterization Conference, Salt Lake City, Utah, October 24-26, 1995.

11. Comparison of Shuffler and Differential Die-Away Technique Instruments for the Assay of Fissile Materials in 55-gal Waste Drums, P. M. Rinard, K. L. Coop, N.J. Nicholas, H.O Menlove, Los Alamos National Laboratory Report LA-UR 93-2649, Los Alamos, New Mexico, July 13, 1993.

12. The Intercomparison of NDA Measurements on CH-TRU Waste Between Nuclear Fuel Services, Inc. and Oak Ridge National Laboratory, J. A. Chapman, F. J. Schultz, D. C. Hensley, 
Proceedings of the 4th Nondestructive Assay and Nondestructive Examination Waste Characterization Conference, Salt Lake City, Utah, October 24-26, 1995.

13. Waste Acceptance Criteria for Transuranic Waste from Nuclear Fuel Services, Inc., WMWMCO-202, Oak Ridge National Laboratory, Oak Ridge, Tennessee, January 1991.

14. A Feasibility Study for a LINAC-Based Transuranic Waste Characterization System, F. J. Schultz, G. Vourvopoulos, P. C. Womble, M. L. Roberts, Journal of Radioanalytical and Nuclear Chemistry, Articles, Vol. 193, No. 2, pg. 369-375, 1995.

15. Notes for Lien Nguyen, REDC Pilot Study Fact Sheet Attachments 1 \& 2, Internal Correspondence from R. E. Schreiber to L. K. Nguyen, Oak Ridge National Laboratory, Oak Ridge, Tennessee, October 1995.

16. User's Manual for the Radioactive Decay and Accumulation Code RADAC, ORNL/TM12380, R. Salmon, S. L. Loghry, R. C. Ashline, Oak Ridge National Laboratory, Oak Ridge, Tennessee, November 1995.

17. WMRAD Quality Management Plan, WMRAD-AD-11, Waste Management and Remedial Action Division, Oak Ridge National Laboratory, Oak Ridge, Tennessee, current revision.

18. Quality Assurance Plan for Contact-Handled Transuranic Waste Certification and Operations, QAP-X-93-WMRA-056, Oak Ridge National Laboratory, Oak Ridge, Tennessee, July 1993. 


\section{INTERNAL DISTRIBUTION}

1-2 Central Research Library

3 Document Reference Section

4-5 Laboratory Records Department

6 Laboratory Records, ORNL-RC

7 ORNL Patent Section

8-10 M\&C Records Office

11 R.L. Auble

12 D.E. Benker

13 J.E. Bigelow

14 R.W. Brandenburg

15 D.E. Brashears

16 D.E. Coffey

17 N. Dailey

18 D. Daugherty

19 J.R. DeVore

20 M. Evans

21 J.R. Forgy

22 W. Griest

23 J. Hackworth

24 R. Hagenauer

25 F. Homan

26 T.D. Hylton

27 J.M. Keller

28 S. Kennedy

29 T. Kent

30 F. Kornegay

31 G.R. Larson

32 C.A. Manrod

33 R. Martin

34 R.C. Mason

35 B.C. McClelland

36 A. Meeks

37 G.T. Mei

38 T. Monk

39 J. Moore

40-41 C. Parks

42 R. Peacher

43 S. Robinson

44 M. Roddye

45 R.D. Bailey

46 T. Rogers

47 J. Saffell
48 T.F. Scanlan

49 R.E. Schreiber

50 D.H. Smith

51 J.L. Stellern

52 J.R. Stokely

53 R.M. Wham

54 J. Williams

55 B.V. Wojtowicz

56 C. Wynn

57-61 J. Chapman

62-66 F.J. Schultz

67-68 D. Downing

69-70 J. Beauchamp

71-72 V. Fedorov

73-74 L. Nguyen

75-79 L. Yong 


\section{EXTERNAL DISTRIBUTION}

80-82 Westinghouse Hanford Corp.

P.O. Box 1970

Richland, WA 99352

M.A. Purcell

MS-T6-51

Richard Lipinski

MS-T3-04

Richard Hamilton

MS-T5-06

83

Ed Pentaleri

SAIC

2950 Patrick Henry Dr.

Santa Clara, CA 95054

84-87 Sandia National Laboratories

P.O. Box 5800

Albuquerque, NM 87185

Ruth F. Weiner

MS-1341

Richard Bild

MS-1335

Lenny Storz

MS-1341

Larry Sanchez

MS-1341

88

Stephen Mettler

Canberra Industries, Inc.

937 W. Altgeld St.

Chicago, IL 60614

89-90 Canberra Industries, Inc.

800 Research Parkway

Meriden, CT 06450

Dorothy R. Davidson

Michael A. Zebarth

91

James R. Fox

Dames \& Moore Inc.

West Valley Demonstration Project

P.O. Box 191, AOC-28

West Valley, NY 14171-0191 
Idaho National Engineering Laboratory

Lockheed Martin Idaho Technologies Company

P.O. Box 1625

Idaho Falls, ID 83415

Clifford J. Stanley MS-4201

Greg K. Becker MS-2114

Tom Clements MS-2424

Yale Harker MS-2114

Larry East MS-2424

Mike Connolly MS-2424

Craig R. Tyler MS-2424

99 Eddie Ashe

Camber Corporation

101 Donner Dr.

Oak Ridge, TN 37830

100-113 Los Alamos National Laboratories

P.O. Box 1663 ,

Los Alamos, NM 87545

Mark M. Pickrell MS-E540

Jim Sprinkle MS-E540

Robert Marshall MS-G740

Michael E. Cournoyer MS-G740

Pete DelMar MS-G730

Ken Bower MS-A117

Bruce R. Erdal MS-J591

Kenneth L. Coop MS-J562

Chris Duy MS-J593

Kathleen Gruetzmacher MS-E501

Dennis L. Hjeresen MS-J591

Deborah J. Figg MS-E518

K. K. S. Pillay MS-E500

Don Close MS-J562

114 James A. Morman

Argonne National Laboratory

9700 S. Cass Ave. Bldg. 207

Argonne, IL 60439

115 Jeff Gross

Lockheed Martin Utility Services

P.O. Box 628, MS-2214

Piketon, $\mathrm{OH} 45669$ 
Charles J. Marcinkiewicz

Contech, Inc.

30 West Patrick Street

Frederick, MD 21701

117

William W. Weston

Long Range Regulatory Compliance

Westinghouse Electric Corporation

P.O. Box 2078, MS-090

Carlsbad, NM 88221

118-119 Lawrence Livermore National Laboratory

P.O. Box 808

7000 East Ave.

Livermore, CA 94550

David Camp

Harry E. Martz, Jr.

120-121 Argonne National Laboratory-West

P.O. Box 2528

Idaho Falls, ID 83403

Robert W. Benedict

David S. Duncan

122-123 Department of Physics

Western Kentucky University

Bowling Green, KY 42101

Ken Lamkin

Stacy Butler-Moore

124-127 U.S. Department of Energy

3 Main

Oak Ridge, TN 37830

Sherry Gibson

Gary Riner

Scott Boeke

Elizabeth Phillips 
128-129 Westinghouse Savannah River Co.

P.O. Box 616

Aiken, SC 29802

Ann Gibbs

Bldg.-707-C

Richard A. Hane

Bldg.-724-9E

130

Jeff Williams

U.S. Department of Energy

Trevion II, EM-36

19901 Germantown Road

Germantown, MD 20874

131

Paul Frame

ORISE

P.O. Box 117

Oak Ridge, TN 37831-0117

132 Clark Barton

Battelle

505 King Avenue

Columbus, OH 43201-2693

133

Kim Piper

Battelle Pacific National Laboratory

P.O. Box 999

Richland, WA 99352

134-136 Waste Isolation Pilot Plant

U.S. Department of Energy

P.O. Box 3090

Carlsbad, NM 88221

Michael Brown

Amber Clay

Russ Bisping

137

Bob Tuttle

Rocketdyne

6633 Canoga Avenue

Canoga Park, GA 93063

138

Kyle E. Rogers

U.S. Environmental Protection Agency

501 3rd St. NW

Washington, DC 20001 
139-140 Office of Scientific \& Technical Information

P.O. Box 62

Oak Ridge, TN 37831 